\title{
REKONSEPTUALISASI GERAKAN DAKWAH JAMAAH TABLIGH KOTA PALOPO
}

\author{
Achmad Sulfikar \\ IAIN Palopo \\ Jl. Agatis, Balandai, Kota Palopo, Sulawesi Selatan, Indonesia \\ E-mail: achmad_sulfikar@iainpalopo.ac.id
}

\begin{abstract}
This study aims to acquire factual knowledge, understanding and expressing a variety of symptoms that arise throughout the process of conveying messages of dakwah by members of Jamaah Tabligh Palopo, and develop concepts, theoretical models, and communication approaches with regard to the role of Jamaah Tabligh as a preacher. Researchers conducted a participant observation of the Jamaah Tabligh Palopo uses dramaturgical theory of Erving Goffman, who use the theater metaphor to analyze human behavior. Through this research, will know what, why and how they're to preach, especially about their impression management in conveying the messages of dakwah. The author found that Jamaah Tabligh is more of a cultural movement, the movement clearly well organized. In the context of dramaturgy there is a clear line between the front stage and back stage, but Jamaah Tabligh give an opportunity to the public to at any time to cross the edge. Actors in this case members of the Jamaah Tabligh tried to play a good role as a preacher, it is dominated by the more spiritual motivation
\end{abstract}

Keywords: Preacer Movement, Jamaah Tabligh

\begin{abstract}
Abstrak
Penelitian ini bertujuan untuk mendapatkan pengetahuan faktual, memahami dan mengungkapkan berbagai gejala yang timbul sepanjang proses penyampaian pesan-pesan dakwah oleh para anggota Jamaah Tabligh Kota Palopo, serta mengembangkan konsep, model teoretis, dan pendekatan komunikasi berkaitan dengan peran Jamaah Tabligh sebagai juru dakwah. Peneliti melakukan pengamatan berperan serta terhadap kelompok Jamaah Tabligh Kota Palopo menggunakan bingkai teori dramaturgi Erving Goffman, yang memanfaatkan metafor teater untuk menganalisis perilaku manusia. Melalui penelitian ini diperoleh gambaran yang objektif tentang apa, mengapa dan bagaimana Jamaah Tabligh berdakwah khususnya dalam pengelolaan kesan (impression management) mereka dalam menyampaikan pesan-pesan dakwah. Penulis mendapati bahwa Jamaah Tabligh adalah lebih kepada sebuah gerakan kultural walaupun demikian, penulis melihat gerakan ini jelas terorganisasi dengan baik. Dalam konteks dramaturgi ada garis yang jelas antara panggung depan dan panggung belakang, tetapi Jamaah Tabligh memberikan peluang kepada khalayak untuk sewaktu-waktu melewati batas panggung. Aktor-aktor dalam hal ini anggota jamaah berusaha memainkan peran yang baik sebagai pendakwah, hal ini didominasi oleh motivasi yang lebih bersifat spiritual
\end{abstract}

Kata Kunci: Gerakan Dakwah, Jamaah Tabligh 


\section{PENDAHULUAN}

Dakwah merupakan kewajiban bagi setiap umat Islam. Kewajiban dan tanggung jawab dalam melakukan dakwah dibebankan kepada seluruh umat Islam sesuai dengan kemampuan dan pengetahuan masing-masing. Namun demikian, tentu saja dakwah yang dilakukan dengan metode yang tepat dan bekal ilmu yang memadai akan menjadikan dakwah akan lebih efektif.

Dakwah merupakan upaya yang dilakukan secara terencana dan penuh kesadaran untuk mengajak orang lain agar memahami dan menjalankan ajaran Islam dalam setiap gerak kehidupan secara total dan konsekuen. Dakwah bukan sesuatu yang sulit jika seseorang telah memahami tujuan dakwah dan memiliki keinginan yang kuat untuk melakukannya, tetapi dakwah juga bukan sesuatu yang bisa dilakukan begitu saja. Dakwah menuntut niat yang kuat, komitmen yang teguh serta kesiapan mental yang tangguh dari dalam diri juru dakwah.

Selain komitmen dan kesiapan mental, dakwah juga memerlukan pengetahuan ilmu agama yang memadai. Hal ini terkait dengan isi pesan dakwah yang akan disampaikan ke khalayak. Isi pesan dakwah yang disampaikan oleh juru dakwah sebagai komunikator idealnya harus sesuai dengan kebutuhan khalayak sebagai komunikan. Kedalaman ilmu yang dimiliki oleh juru dakwah akan menjadikan isi pesan lebih berisi dan akan lebih mampu memberikan pencerahan dan solusi atas berbagai masalah yang dihadapi oleh umat.

Pesan-pesan dakwah yang disampaikan oleh juru dakwah yang memiliki kedalaman pengetahuan yang baik perlu disampaikan dengan menggunakan metode yang tepat. Di sinilah letak persinggungan antara kegiatan dakwah dan ilmu komunikasi. Dibutuhkan pengetahuan tentang ilmu komunikasi dan kemampuan untuk melakukan komunikasi yang benar agar pesan-pesan dakwah sampai kepada umat dengan pemahaman yang benar sesuai tujuan juru dakwah.

Dalam berdakwah, juru dakwah sebagai komunikator sebelumnya perlu mengidentifikasi elemen-elemen komunikasi. Mulai dari sisi komunikator itu sendiri, isi pesan, media yang akan digunakan, dan sasaran dakwah atau komunikan, serta tidak lupa memikirkan efek dan dampak isi pesan dakwah yang disampaikan. Sukses tidaknya dakwah yang dilakukan tergantung dari identifikasi elemen-elemen komunikasi ini. Identifikasi ini juga nantinya akan penting sebagai bahan evaluasi terhadap kegiatan dakwah yang telah dilakukan. Evaluasi perlu dilakukan setelah melakukan berdakwah untuk mengetahui kekurangan dan hal-hal yang membuat kegiatan dakwah tidak efektif.

Metode dan teknik komunikasi sendiri berkembang seiring dengan kemajuan teknologi komunikasi. Teknologi komunikasi erat kaitannya 
dengan peradaban manusia. Hal ini juga penting dipahami oleh juru dakwah. Metode komunikasi dalam kegiatan dakwah harus berevolusi karena sasaran dakwah atau khalayak mengalami evolusi teknologi. Segala bentuk saluran pesan atau media moderen perlu dimanfaatkan secara maksimal sebagai sarana dakwah untuk menjawab tuntutan kemajuan teknologi. Seorang juru dakwah tidak boleh mengalami gagap teknologi jika ingin misi dakwah yang dilakukan tepat sasaran dan mencapai target yang diinginkan.

Di tengah tuntutan untuk melakukan dakwah yang moderen sesuai perkembangan teknologi dan peradaban manusia, peneliti melihat sebuah fenomena menarik terjadi di depan mata. Sebuah gerakan dakwah yang bersahaja dan tradisional hadir di tengah-tengah masyarakat Indonesia, termasuk di Kota Palopo Propinsi Sulawesi Selatan. Gerakan dakwah ini secara umum dikenal dengan nama Jamaah Tabligh. Selain nama Jamaah Tabligh sebagian orang juga menyebut gerakan dakwah ini sebagai Jamaah Khuruj, Jamaah Ta'lim, dan Jamaah Jaulah.

Dalam berdakwah Jamaah Tabligh tampil secara sangat sederhana. Kesederhanaan tersebut nampak mulai dari cara berpakaian hingga metode dakwah yang dilakukan. Jamaah Tabligh tidak menggunakan media moderen dalam menyampaikan pesan-pesan dakwahnya. Jamaah Tabligh memilih untuk melakukan pertemuan secara langsung dengan sasaran dakwah mereka, kunjungan ke rumah-rumah, bahkan orang-orang yang tidak sengaja ditemui di tempat-tempat umum tidak luput menjadi sasaran dakwah mereka.

Berdasarkan pengamatan dan informasi pra penelitian yang peneliti lakukan, ada empat kegiatan utama dakwah Jamaah Tabligh. Pertama, khuruj yakni meninggalkan kampung halaman untuk berdakwah; Kedua jaulah yakni mengujungi atau silaturrahmi ke rumah orang-orang yang dituju, ke pertokoan atau ke pasar-pasar mengajak orang untuk shalat berjamaah, meningkatkan iman, dan memperbanyak amal kebaikan; Ketiga bayan atau ceramah di markas, teknis pelaksanaannya yaitu semua orang yang mengikutinya harus duduk mendekati pemberi materi secara rapat-rapat; Terakhir ta'lim wa ta'allum atau kegiatan belajar-mengajar yang dilakukan Jamaah Tabligh di mesjid atau musalla. Dari uraian kegiatan utama tersebut kita bisa mengetahui bahwa semua kegiatan dakwah Jamaah Tabligh dilakukakan dengan bertemu langsung atau tatap muka.

Apa yang dilakukan oleh komunitas Jamaah Tabligh dalam berdakwah merupakan hal yang menarik untuk dikaji secara ilmiah, utamanya terkait dengan studi ilmu komunikasi. Ilmu komunikasi menjelaskan bahwa setiap gerak, tingkah laku dan kegiatan manusia didasari oleh motif-motif tertentu. Ada makna dan tujuan dari setiap laku dan gerak manusia. Ada beragam alasan yang menggerakkan manusia untuk berkomunikasi dengan orang lain. 
Menarik untuk mengetahui apa motivasi anggota Jamaah Tabligh dalam berdakwah, bagaimana anggota Jamaah Tabligh memaknai kegiatan mereka, bagaimana persiapan mereka sebelum berdakwah, dan apa yang mereka lakukan agar umat tertarik dengan isi pesan dakwah mereka.

\section{INTERAKSIONISME SIMBOLIK: INSPIRASI BAGI DRAMATURGI}

Pendekatan dramaturgi pertama kali dikembangkan oleh Erving Goffman setelah melakukan berbagai bidang kajian sosiologi, antropologi dan komunikasi. Pendekatan dramaturgi oleh Erving Goffman sendiri banyak dipengaruhi oleh George Mead dan Herbert Blumer. Berbicara tentang Dramaturgi memang tidak akan lengkap tanpa menyebut perspektif Interaksionisme Simbolik yang digagas oleh Herbert Mead.

Pemahaman mengenai dramaturgi Goffman didasari oleh gagasan Mead mengenai makna, bahasa, dan pemikiran, yang kemudian dirumuskan oleh Blumer hingga menjadi apa yang disebut interaksionisme simbolik. ${ }^{1}$ Perspektif interaksionisme simbolik sebelumnya lebih dikenal dalam ilmu sosiologi, tetapi saat ini pengaruhnya telah masuk ke dalam kajian disiplin yang berbeda seperti antropologi, psikologi, dan ilmu komunikasi. Littlejohn memasukkan persinggungan disiplin sosiologi dan komunikasi dalam interaksionisme simbolik ini ke dalam Tradisi Sosiokultural dalam kumpulan teori komunikasi yang disusunnya. ${ }^{2}$

Para pakar interaksionisme simbolik menyebutkan bahwa tindakan terbagi ke dalam dua macam, yaitu tindakan nyata dan tersembunyi. Tindakan tersembunyi adalah memasuki pikiran manusia. Tindakan tersembunyi mengharuskan peneliti memahami tingkah laku manusia yang mendefinisikan situasi aktual, bagaimana mereka mengembangkan, menggunakan, dan mengubah perspektif, memilih peran, dan mengambil sebuah keputusan. ${ }^{3}$

Menurut Blumer, bagi seorang ilmuwan itu sendiri untuk mengerti tentang suatu hal diperlukan kemampuan menempatkan diri sendiri pada individu atau kelompok. ${ }^{4}$ Jadi interaksi interaksionisme simbolik merupakan cara berpikir mengenai pikiran, diri sendiri, dan masyarakat. Interaksionisme simbolik mengajarkan bahwa sepanjang waktu manusia berinteraksi satu sama lain, mereka saling berbagi pengertian untuk istilah-istilah dan

${ }^{1}$ Em Griffin, Communication Theory, 4th Edition (The McGraw-Hill Companies, 2000), 54.

2 Stephen W Littlejohn dan Karen A Foss, Teori Komunikasi (Jakarta: Salemba Humanika, 2009), 120.

${ }^{3}$ Deddy Mulyana dan Solatun, Metode Penelitian Komunikasi; Contoh-Contoh Penelitian Kualitatif Dengan Pendekatan Praktis (Bandung: Remaja Rosdakarya, 2007), 36.

4 Ibid., 37. 
tindakan tertentu dan memahami kejadian-kejadian dalam cara-cara yang tertentu pula. ${ }^{5}$

Teori interaksi simbolik berpegang bahwa individu membentuk makna melalui proses komunikasi karena makna tidak bersifat intrinsik terhadap apapun. Dibutuhkan konstruksi interpretif di antara orang-orang untuk menciptakan makna. Tujuan interaksi menurut interaksionisme simbolik adalah untuk menciptakan makna yang sama. Tanpa makna yang sama berkomunikasi akan menjadi sangat sulit, bahkan tidak mungkin. ${ }^{6}$

Menurut Ralph LaRossa dan Donald C. Reitzes, gagasan mengenai pembentukan makna melalui proses komunikasi mendukung tiga asumsi interaksionisme simbolik yang diambil dari karya Herbert Blummer ${ }^{7}$. Asumsi-asumsi ini adalah sebagai berikut:

1. Manusia bertindak terhadap manusia lainnya berdasarkan makna yang diberikan orang lain pada mereka.

2. Makna diciptakan dalam interaksi antar manusia.

3. Makna dimodifikasi melalui proses interpretif.

Dalam karya Herbert Mead yang paling terkenal berjudul Mind, Self and Society menekankan tiga konsep kritis yang diperlukan dalam menyusun diskusi tentang teori interaksionisme simbolik. Hal pertama yang harus dicatat adalah bahwa tiga konsep ini saling mempengaruhi satu sama lain dalam terminologi interaksionisme simbolik. Dari itu, pikiran manusia (mind) dan interaksi sosial (diri/self dengan yang lain) digunakan untuk menginterpretasikan dan memediasi masyarakat (society) di mana kita hidup. Makna berasal dari interaksi dan tidak diperoleh melalui cara yang lain. Pada saat yang sama, "pikiran" dan "diri" muncul dalam konteks sosial masyarakat. Hubungan dan pengaruh timbal-balik antara masyarakat, pengalaman individu, dan interaksi menjadi bahan bagi pengkajian dalam tradisi interaksionisme simbolik. ${ }^{8}$

Mead menggunakan beragam konsep untuk menyempurnakan cara lahirnya makna melalui interaksi dalam kelompok sosial. Sebagai contoh Mead berbicara tentang simbol signifikan (significant symbols) dengan makna yang sama dalam sebuah masyarakat. Tanpa sistem penyimbolan yang sama, tidak mungkin ada aksi yang terkoordinasi. Konsep penting lainnya dalam teori interaksionisme simbolik adalah orang lain yang signifikan (significant others), yaitu "orang yang berpengaruh dalam kehidupan anda", lalu orang

${ }^{5}$ Stephen W Littlejohn dan Karen A Foss, Teori Komunikasi, 121.

${ }^{6}$ Richard West dan Lynn H Turner, Introducing Communication Theory: Analysis and Application (Jakarta: Salemba Humanika, 2009), 99.

${ }^{7}$ Richard West dan Lynn H Turner, Introducing Communication Theory: Analysis and Application. 1934).

${ }^{8}$ George Herbert Mead, Mind, Self, and Society (Chicago: University Of Chicago Press, 
lain yang digeneralisasikan (generalized others) yakni konsep anda tentang bagaimana orang lain merasakan anda, dan "tata cara yang dipakai" (role taking) yaitu pembentukan perilaku setelah perilaku orang lain. Konsep ini disusun bersama dalam teori interaksionisme simbolik untuk menyediakan sebuah gambaran yang kompleks dari pengaruh persepsi individu dan kondisi psikologis, komunikasi simbolik, serta nilai sosial dan keyakinan dalam sebuah konstruksi sosial masyarakat. ${ }^{9}$

Dari uraian di atas diketahui bahwa teori ini berpandangan bahwa kenyataan sosial didasarkan kepada definisi dan penilaian subjektif individu. Struktur sosial adalah merupakan defenisi bersama yang dimiliki individu yang berhubungan dengan bentuk-bentuk yang cocok, yang menghubungkannya satu sama lain. Tindakan-tindakan individu dan juga pola interaksinya dibimbing oleh defenisi bersama yang sedemikian itu, dan dikonstruksikan melalui proses interaksi. Teori interaksionisme simbolik merupakan sebuah kerangka teori yang kuat yang masih sanggup bertahan dalam kurun waktu kurang lebih 60 tahun, hal ini membuktikan bahwa secara kriteria waktu teori ini dianggap memuaskan. Teori ini menyediakan pandangan yang menonjol tentang perilaku komunikasi antar manusia dalam konteks yang sangat luas dan variatif.

\section{DRAMATURGI: DRAMA KEHIDUPAN MANUSIA}

Teori dramaturgi Erving Goffman yang terinspirasi dari interaksionisme simbolik menyebabkan Goffman sering dianggap sebagai salah satu penafsir teori diri Mead yang menenkankan pada sifat simbolik dari manusia. Melalui karyanya yang berjudul The Presentation of Self in Everyday Life (1956), Goffman menguraikan tentang bagaimana seseorang tampil di dunia sosial. Dalam karyanya ini Goffman tidak menekankan perhatiannya kepada struktur sosial. Ia lebih tertarik pada interaksi tatap muka atau kehadiran bersama (co-presence). ${ }^{10}$

Goffman mengawali penalarannya dengan sebuah asumsi bahwa setiap orang dalam berinteraksi antar pribadi selalu berhadapan dengan situasi yang harus ditangkapnya sebagai pembentuk atau pengorganisir setiap kejadian. Jadi, menurut Goffman apa yang muncul sebagai suatu peristiwa yang terorganisir dari seorang individu telah menghasilkan suatu kenyataan yang sesaat bagi orang itu. Premis ini sangat fenomenologis yang

9 Kathleen K Reardon, Interpersonal Communication: Where Mind Meets (Belmont: Wadsworth Publishing Company, 1987), 27.

10 Deddy Mulyana dan Solatun, Metode Penelitian Komunikasi; Contoh-Contoh Penelitian Kualitatif Dengan Pendekatan Praktis, 38. 
menyatakan bahwa apa yang menjadi kenyataan yang dihadapi seseorang itu juga yang menjadi definisi dari situasi orang tersebut. ${ }^{11}$

Bagi Erving Goffman, kehidupan ini diibaratkan sebuah panggung pertunjukan teater yang menampilkan aktor-aktor yang saling berinteraksi. ${ }^{12}$ Manusia adalah aktor yang menyusun penampilan mereka untuk memberikan kesan kepada audience yang menontonnya. Goffman membagi wilayah pertunjukan kehidupan sosial ke dalam dua bagian;

1. Front Region (wilayah depan), yaitu peristiwa sosial yang memungkinkan individu bergaya atau menampilkan peran formalnya, sebagaimana mereka sedang memainkan satu peran di atas panggung. Wilayah ini disebut juga sebagai "panggung depan" (front stage). ${ }^{13}$

2. Back Region (wilayah belakang), yaitu tempat atau peristiwa yang memungkinkan aktor untuk melakukan persiapan atau latihan sebelum tampil di panggung depan. Wilayah ini disebut juga sebagai "panggung belakang" (back stage). ${ }^{14}$

Di panggung depan para aktor menggunakan kesempatan untuk membentuk image dan memainkan pertunjukan sesuai dengan skenario yang telah dibuat di panggung belakang yang sangat berbeda dengan yang terjadi di panggung belakang. Pada bagian yang lain penampilan aktor secara teratur berfungsi secara umum untuk tetap konsisten mendefinisikan situasi bagi mereka yang menyaksikan penampilan itu, selain itu dikenal juga setting (set panggung) dan personal front (perangkat pribadi) yang kemudian dibagi lagi menjadi appearance (penampilan) dan manner (gaya). ${ }^{15}$

Menurut Medlin tujuan utama setiap pertunjukan adalah menjaga agar setiap pertunjukan berjalan sesuai dengan apa yang didefinisikan oleh aktor. ${ }^{16}$ Untuk mencapai tujuan tersebut aktor akan melakukan kontrol terhadap front stage, dan menyembunyikan elemen apa saja yang bisa merusak dari audience.

Elemen yang bisa merusak ini antara lain adalah pada saat "aktor terlalu banyak mengkomunikasikan fakta tertentu dan kurang mengkomunikasikan fakta yang lain". Oleh sebab itu kontrol terhadap informasi (information control) adalah salah satu cara mencegah munculnya elemen yang merusak tersebut. ${ }^{17}$

\footnotetext{
${ }^{11}$ Alo Liliweri, Perspektif Teoritis, Komunikasi Antar Pribadi: Suatu Pendekatan Ke Arah Psikologi Sosial Komunikasi (Bandung: Citra Aditya Bakri, 1994), 148.

12 Erving Goffman, The Presentation of Self in Everyday Life (Edinburgh: University of Edinburgh Social Sciences Research Centre, 1956), 17.

13 Ibid., 66.

14 Ibid., 69.

15 Ibid., 15.

${ }^{16}$ A. K. Medlin, Bargain Theater: A Dramaturgical Analysis of a Flea Market (Auburn: Auburn University, 2008), 47.

${ }^{17}$ A. K. Medlin, Bargain Theater: A Dramaturgical Analysis of a Flea Market.
} 


\section{6 | Achmad Sulfikar}

Dalam perspektif dramaturgi, Goffman mendefinisikan seni manajemen impresi sebagai tindakan menjaga hal-hal yang tidak diinginkan yang dapat menimbulkan rasa malu dan memicu pertengkaran. Ada empat macam kejadian yang dapat terjadi di luar dari rencana pertunjukan, Goffman menyebutnya sebagai insiden dramaturgi: ${ }^{18}$

1. Unintended Gestures (gerakan yang tidak disengaja), yaitu gerakan yang dilakukan oleh aktor yang tidak diniatkan sebelumnya Iyang mendiskreditkan jalannya pertunjukan.

2. Inappropriate Intrusion (intrusi yang tidak pantas) yaitu situasi ketika audience memasuki panggung belakang dan menemukan aktor yang dalam keadaan tidak sesuai dengan kesan yang ada ditampilkan di panggung depan.

3. Faux Pas (kecerobohan) yaitu informasi tentang kehidupan aktor yang apabila terungkap oleh audience akan mengurangi impresi yang ditampilkan dalam pertunjukan.

4. Scene (kejadian) yaitu ketika seorang aktor secara individu mendiskreditkan pertunjukan, meskipun pendiskreditan terjadi tanpa disengaja hasilnya akan nampak dan akan tetap menimbulkan konflik. Di lain pihak, mungkin salah satu audience merasa tidak bisa mentolerir jalannya pertunjukan yang sedang dimainkan dan melakukan konfrontir antara aktor dengan ucapan atau tindakan represif yang tidak dapat diterima. Ada pula kemungkinan aktor merasa sangat yakin dengan apa yang dipertunjukkan, namun hal tersebut justru ditolak oleh audience yang akhirnya berujung pada rasa malu.

\section{DAKWAH: KOMUNIKASI INSTRUMENTAL}

Seperti yang sudah peneliti kemukakan sebelumnya bahwa bekal niat baik, komitmen, dan pengetahuan agama yang luas yang dimiliki oleh juru dakwah belum lengkap tanpa pengetahuan ilmu komunikasi yang memadai, baik secara teori maupun praktik. Dakwah adalah salah satu bentuk kegiatan komunikasi yang memiliki ciri khas tersendiri yang berbeda dengan kegiatan komunikasi lainnya. Dalam pesan dakwah terdapat ajakan kepada kebaikan yang didasari oleh misi amr ma'ruf nahy munkar, secara spesifik orientasi pesan dakwah berada di seputar masalah kehidupan manusia menurut ajaran Islam. ${ }^{19}$ Isi pesan dakwah yang khas tersebut selaras dengan tujuan dakwah yang juga khas, H. M. Arifin menyatakan bahwa tujuan program kegiatan dakwah adalah untuk menumbuhkan pengertian, kesadaran,

\footnotetext{
18 Ibid., 55-57.

${ }^{19}$ Muhazzab Said, "Komunikasi Dalam Perspektif Dakwah," PSW STAIN Palopo, 2008,
} 29.

\section{PALITA: Journal of Social-Religi Research}


penghayatan dan pengamalan ajaran agama yang dibawakan oleh aparat dakwah. ${ }^{20}$

Sebagai sebuah gejala komunikasi, dakwah sudah sepatutnya dilengkapi sejumlah peralatan studi sesuai dengan yang telah disediakan oleh konsep-konsep, teori-teori, model-model, yang akan sangat berguna dalam mempelajari penyebaran dan penyerapan ide-ide dakwah. ${ }^{21}$ Secara umum kegiatan dakwah tidak berbeda dengan elemen-elemen komunikasi yang di dalamnya juga terdapat sumber, pesan, saluran, penerima, umpan balik, dan pengaruh.

Dari uraian mengenai isi pesan dan tujuan dakwah di atas, dakwah secara fungsional termasuk dalam kategori komunikasi instrumental. Komunikasi instrumental mempunyai beberapa tujuan umum: menginformasikan, mengajar, mendorong, mengubah sikap dan keyakinan, mengubah perilaku atau menggerakkan tindakan, dan juga menghibur. Bila diringkas, maka semua tujuan tersebut dapat disebut membujuk atau bersifat persuasif. Komunikasi yang berfungsi memberitahukan atau menerangkan (to inform) mengandung muatan persuasif dalam arti bahwa pembicara menginginkan pendengarnya memercayai bahwa fakta atau informasi yang disampaikannya akurat dan layak diketahui. ${ }^{22}$

Sebagai sebuah instrumen, komunikasi tidak saja bisa digunakan untuk menciptakan dan membangun hubungan, namun juga untuk menghancurkan hubungan tersebut. Studi komunikasi membuat kita peka terhadap berbagai strategi yang dapat kita gunakan dalam komunikasi kita untuk bekerja lebih baik dengan orang lain untuk keuntungan bersama. Komunikasi berfungsi sebagai instrumen untuk tujuan-tujuan pribadi dan pekerjaan, baik tujuan jangka pendek ataupun tujuan jangka panjang. Tujuan jangka pendek misalnya untuk memperoleh pujian, menumbuhkan kesan yang baik, memperoleh simpati, empati, keuntungan material, ekonomi, dan politik yang antara lain dapat diraih lewat pengelolaan kesan (impression management), yakni taktik-taktik verbal dan non verbal, seperti berbicara sopan, mengobral janji, mengenakan pakaian yang necis, dan sebagainya yang pada dasarnya untuk menunjukkan kepada orang lain siapa diri kita seperti yang kita inginkan. ${ }^{23}$

${ }^{20}$ H.M. Arifin, Psikologi Dakwah, Suatu Pengantar Studi, 3 ed. (Jakarta: Bumi Aksara, 1994), 4.

21 Muhazzab Said, "Komunikasi Dalam Perspektif Dakwah."

22 Deddy Mulyana, Komunikasi: Suatu Pengantar, IX (Bandung: Remaja Rosdakarya, 2007), 33.

23 Deddy Mulyana, Nuansa-Nuansa Komunikasi: Meneropong Politik Dan Budaya Komunikasi Masyarakat Kontemporer (Bandung: Remaja Rosdakarya, 1999), 87-92. 


\section{METODOLOGI PENELITIAN}

Penelitian ini menggunakan metodologi kualitatif dalam paradigma interpretif (fenomenologis) khususnya pendekatan dramaturgis yang merupakan bagian dari interaksionisme simbolik. Untuk mengungkap realitas sosial seperti gerakan dakwah Jamaah Tabligh secara apa adanya, peneliti menggunakan teknik primer berupa pengamatan berperan-serta (participant observation) untuk mengetahui proses komunikasi dalam dakwah sehari-hari anggota Jamaah Tabligh Kota Palopo. Pengamatan berperan-serta adalah upaya utama peneliti untuk mengumpulkan data dengan cara menjadi bagian atau terasosiasikan dengan objek penelitian. Teknik ini berbasis logika penemuan (logic of discovery), sehingga teknik pengamatan berperan-serta memiliki kelebihan apabila digunakan untuk meneliti pola manusia berperilaku serta memandang realitas kehidupan mereka dalam kehidupan yang biasa dan rutin. Ini disebabkan perilaku manusia tidak cocok diteliti dalam sebuah lingkungan buatan, yang bisa dipastikan dapat membuat mereka berperilaku tidak alamiah. Dalam pengamatan ini peneliti melakukan pencatatan secara sistematis mengenai aktifitas Jamaah Tabligh, selain itu penggunaan bahasa dan lambang dalam penyampaian pesan-pesan dakwah juga termasuk dalam pengamatan. Sebuah prosedur pengamatan berperan-serta yang dikenal dengan prosedur "mencuri dengar" (eavesdroping) dan "pelacak" (tracer) juga peneliti lakukan untuk memperoleh data penelitian.

Wawancara juga dilakukan dengan informan yang terdiri dari anggota Jamaah Tabligh Kota Palopo. Wawancara dilakukan bertujuan untuk sebagai pelengkap teknik primer di atas agar sifat-sifat tertutup tindakan sosial serta sifatnya yang terbuka dapat diamati, sehingga memberikan gambaran komprehensif tentang subyek penelitian melalui perbandingan apa yang dikatakan dengan apa yang dilakukan ketika berada dalam situasi tertentu. Hasil wawancara tersebut ditunjang data fisik dan rekaman kegiatan selama proses pesan-pesan dakwah disampaikan selanjutnya dianalisis. Konfirmasi intersubjektif dilakukan dengan para informan lainnya pada saat penelitian berjalan dengan teknik snowball, analisis pada konfirmasi intersubjektif dilakukan secara terus menerus selama proses penelitian.

\section{DAKWAH JAMAAH TABLIGH KOTA PALOPO}

\section{Panggung Depan (Front Stage)}

Goffman membagi dua kawasan depan; set panggung (setting) dan perangkat pribadi (personal front). Bila diterapkan dalam konteks Jamaah Tabligh Kota Palopo maka setting yang melekat padanya adalah; Khuruj; berarti keluar berdakwah di jalan Allah. Khuruj perlu keyakinan dan motivasi 
yang kuat karena meninggalkan keluarga, anak, istri pekerjaan, harta untuk menuju ke berbagai tempat menemui umat Islam yang lain untuk menjalankan amar ma'ruf nahi munkar. Khuruj ini digunakan sebagai landasan kemantapan berdakwah dan bertabligh untuk menyampaikan pesan dakwah. Dalam konteks dramaturgi khuruj adalah panggung utama Jamaah Tabligh.

Khuruj terbagi dua, yaitu jamaah jalan kaki dan jamaah biasa. Masa melakukan Khuruj bervariasi. Ada yg dilakukan dalam waktu sore hari dalam seminggu, tiga hari dalam sebulan, 40 hari dalam setahun atau empat bulan dalam seumur hidup. Tempat atau lokasi khuruj akan ditujukan ke masjidmasjid yg sebelumnya telah ditetapkan oleh jamaah. Mereka kemudian bergerak dari satu masjid ke masjid itu. Sebagai contoh, jika mereka khuruj selama 40 hari, ada 13 buah masjid yang dijadikan tempat khuruj secara bergilir.

Sedangkan personal front adalah perangkat yang dianggap audience dapat menunjukkan identitas dan status sebagai anggota Jamaah Tabligh. Dalam menampilkan personal front di panggung depan Jamaah Tabligh tampil bersahaja. Jamaah Tabligh meyakini bahwa setiap aspek dalam hidup harus mengikuti apa yang pernah dilakukan oleh Rasulullah SAW. Hal ini nampak mencolok dari cara mereka berpakaian. Anggota Jamaah Tabligh memakai pakaian yang diyakini sebagai model pakaian Nabi Muhammad SAW, yaitu memakai jubah, sorban, ikat kepala, memelihara janggut, makan dengan tangan tanpa memakai sendok garpu, dan lebih banyak di masjid. Sedangkan bagi anggota perempuan menggunakan jubah dan cadar serta dan menggunakan warna gelap.

Dalam kehidupan bermasyarakat anggota Jamaah Tabligh berusaha masuk ke dalam berbagai kalangan, mereka meyakini bahwa setiap kegiatan sosial yang mereka kerjakan mengandung nilai dakwah. Anggota Jamaah Tabligh tidak mengesampingkan hubungan dengan masyarakat di sekitar tempat tinggal mereka. Hal ini kemudian sedikit banyak membentuk persepsi positif dari masyarakat terhadap Jamaah Tabligh.

\section{Panggung Belakang (Back Stage)}

Back Stage (panggung belakang) yang merujuk pada tempat atau peristiwa sosial yang memungkinkan anggota Jamaah Tabligh melakukan persiapan peran untuk panggung depan. Ketika melakukan khuruj, setiap jamaah diwajibkan patuh kepada beberapa hal berikut; Enam prinsip Jamaah Tabligh. Prinsip-prinsip tersebut ialah kalimah tayyibah, kalimat syahadat yang ditopang oleh keyakinan yg kuat akan makna kalimat tersebut, solat khusyu' wa al-khudu' adalah shalat dengan konsentrasi batin dan merendahkan diri di hadapan Allah Swt, ilmu dan zikir meyakini setiap ilmu 
yang dimiliki harus disertai dengan perasaan selalu ingat kepada Allah Swt., ikram al-muslimin adalah memuliakan setiap muslim dan memperlakukannya dengan penuh penghargaan, keikhlasan niat dalam melakukan aktivitas dakwah, dan terakhir berdakwah dan tabligh, sifat terakhir ini merupakan ciri khas Jamaah Tabligh yang artinya mengajak dan menyampaikan Islam ke berbagai tempat dengan jalan dakwah.

Kontrol Terhadap Informasi (Information Control)

Information Control (kontrol terhadap informasi) yang akan menjelaskan usaha dari Jamaah Tabligh dalam mengontrol informasi atau pesan yang akan disampaikan kepada khalayak. Dalam konteks Jamaah Tabligh hal ini bisa dilihat pada landasan kerja mereka yang berbentuk musyawarah. Musyawarah dilakukan di masjid yang telah ditentukan untuk menjadi pusat segala aktivitas yang disebut Markaz. Di tempat ini para anggota Jamaah Tabligh melakukan ijtima' atau pertemuan. Pertemuan tersebut biasa dilakukan pada malam hari. Dalam pertemuan tersebut dibentuk jamaah-jamaah yang akan berangkat untuk berdakwah. Pada pertemuan itu pula diadakan bayan bagi seluruh anggota. Seorang jamaah ditunjuk untuk menguraikan bayan (mubayyin), memberikan motivasi dan nasehat kepada jamaah untuk mengambil tanggung jawab agama dengan mengorbankan ego dan meluangkan waktu untuk keluar berdakwah di jalan Allah. Pada akhir bayan, mubayyin menutupnya dengan penawaran dan bujukan kepada jamaah untuk khuruj fi sabilillah (tasykil). Konsolidasi dan "evaluasi" juga dilakukan di markaz. Anggota jamaah yang baru kembali dari berdakwah di berbagai wilayah berkumpul untuk menyampaikan pengalaman masing-masing. Meskipun terlihat sebagai gerakan kultural tetapi aktivitas di markaz memperlihatkan bahwa gerakan ini terorganisir dengan baik.

\section{Manajemen Impresi (Impression Management)}

Impression Management (manajemen impresi) akan menjelaskan tindakan yang dilakukan untuk menjaga munculnya hal-hal yang tidak diinginkan yang dapat berujung pada rasa malu atau pertengkaran yang akan merusak penampilan secara keseluruhan. Manajemen impresi yg melekat pada Jamaah Tabligh adalah menghindari empat hal yang dianggap bisa menimbulkan konflik serta perpecahan yang justru akan kontra produktif terhadap kegiatan dakwah itu sendiri. Empat hal tersebut adalah pembicaraan mengenai politik, mazhab, pangkat dan derajat, serta khilafiyah atau perbedaan pendapat mengenai fiqh. Atas dasar inilah hampir sebagian besar anggota Jamaah Tabligh tidak melibatkan diri dalam dunia politik praktis maupun partisan dan berusaha menjauhinya. 


\section{PENUTUP}

Dalam kehidupan bermasyarakat anggota Jamaah Tabligh berusaha masuk ke dalam berbagai kalangan, mereka meyakini bahwa setiap kegiatan sosial yang mereka kerjakan mengandung nilai dakwah. Anggota Jamaah Tabligh tidak mengesampingkan hubungan dengan masyarakat di sekitar tempat tinggal mereka. Hal ini kemudian sedikit banyak membentuk persepsi positif dari masyarakat terhadap Jamaah Tabligh.

Dalam konteks Jamaah Tabligh Kota Palopo, setting yang melekat padanya adalah; Khuruj; berarti keluar berdakwah di jalan Allah. Khuruj perlu keyakinan dan motivasi yang kuat karena meninggalkan keluarga, anak, istri pekerjaan, harta untuk menuju ke berbagai tempat menemui umat Islam yang lain untuk menjalankan amar ma'ruf nahi munkar. Khuruj ini digunakan sebagai landasan kemantapan berdakwah dan bertabligh untuk menyampaikan pesan dakwah. Dalam konteks dramaturgi khuruj adalah panggung utama Jamaah Tabligh.

Sedangkan personal front adalah perangkat yang dianggap audience dapat menunjukkan identitas dan status sebagai anggota Jamaah Tabligh. Dalam menampilkan personal front di panggung depan Jamaah Tabligh tampil bersahaja. Jamaah Tabligh meyakini bahwa setiap aspek dalam hidup harus mengikuti apa yang pernah dilakukan oleh Rasulullah SAW. Hal ini nampak mencolok dari cara mereka berpakaian. Anggota Jamaah Tabligh memakai pakaian yang diyakini sebagai model pakaian Nabi Muhammad SAW, yaitu memakai jubah, sorban, ikat kepala, memelihara janggut, makan dengan tangan tanpa memakai sendok garpu, dan lebih banyak di masjid. Sedangkan bagi anggota perempuan menggunakan jubah dan cadar serta dan menggunakan warna gelap.

\section{DAFTAR PUSTAKA}

A. K. Medlin. Bargain Theater: A Dramaturgical Analysis of a Flea Market. Auburn: Auburn University, 2008.

Alo Liliweri. Perspektif Teoritis, Komunikasi Antar Pribadi: Suatu Pendekatan Ke Arah Psikologi Sosial Komunikasi. Bandung: Citra Aditya Bakri, 1994.

Deddy Mulyana. Komunikasi: Suatu Pengantar. IX. Bandung: Remaja Rosdakarya, 2007.

-_- Nuansa-Nuansa Komunikasi: Meneropong Politik Dan Budaya Komunikasi Masyarakat Kontemporer. Bandung: Remaja Rosdakarya, 1999.

Deddy Mulyana, dan Solatun. Metode Penelitian Komunikasi; Contoh-Contoh Penelitian Kualitatif Dengan Pendekatan Praktis. Bandung: Remaja Rosdakarya, 2007.

Em Griffin. Communication Theory. 4th Edition. The McGraw-Hill Companies, 2000. 
Erving Goffman. The Presentation of Self in Everyday Life. Edinburgh: University of Edinburgh Social Sciences Research Centre, 1956.

George Herbert Mead. Mind, Self, and Society. Chicago: University Of Chicago Press, 1934.

H.M. Arifin. Psikologi Dakwah, Suatu Pengantar Studi. 3 ed. Jakarta: Bumi Aksara, 1994.

Kathleen K Reardon. Interpersonal Communication: Where Mind Meets. Belmont: Wadsworth Publishing Company, 1987.

Muhazzab Said. "Komunikasi Dalam Perspektif Dakwah.” PSW STAIN Palopo, 2008, 29.

Richard West, dan Lynn $\mathrm{H}$ Turner. Introducing Communication Theory: Analysis and Application. Jakarta: Salemba Humanika, 2009.

Stephen W Littlejohn, dan Karen A Foss. Teori Komunikasi. Jakarta: Salemba Humanika, 2009. 